AperTO - Archivio Istituzionale Open Access dell'Università di Torino

A 4-year observation in lupus nephritis patients treated with an intensified B-lymphocyte depletion without immunosuppressive maintenance treatment-Clinical response compared to literature and immunological re-assessment

This is the author's manuscript

Original Citation:

Availability:

This version is available http://hdl.handle.net/2318/1545463

since 2016-10-20T16:25:03Z

Published version:

DOI:10.1016/j.autrev.2015.07.017

Terms of use:

Open Access

Anyone can freely access the full text of works made available as "Open Access". Works made available under a Creative Commons license can be used according to the terms and conditions of said license. Use of all other works requires consent of the right holder (author or publisher) if not exempted from copyright protection by the applicable law. 
This Accepted Author Manuscript (AAM) is copyrighted and published by Elsevier. It is posted here by agreement between Elsevier and the University of Turin. Changes resulting from the publishing process - such as editing, corrections, structural formatting, and other quality control mechanisms - may not be reflected in this version of the text. The definitive version of the text was subsequently published in AUTOIMMUNITY REVIEWS, None, $2015,10.1016 / \mathrm{j}$.autrev.2015.07.017.

You may download, copy and otherwise use the AAM for non-commercial purposes provided that your license is limited by the following restrictions:

(1) You may use this AAM for non-commercial purposes only under the terms of the CC-BY-NC-ND license.

(2) The integrity of the work and identification of the author, copyright owner, and publisher must be preserved in any copy.

(3) You must attribute this AAM in the following format: Creative Commons BY-NC-ND license (http://creativecommons.org/licenses/by-nc-nd/4.0/deed.en), 10.1016/j.autrev.2015.07.017

The publisher's version is available at:

http://linkinghub.elsevier.com/retrieve/pii/S1568997215001664

When citing, please refer to the published version.

Link to this full text:

http://hdl.handle.net/2318/1545463 


\section{A 4-year observation in lupus nephritis patients treated with an intensified B-lymphocyte depletion without immunosuppressive maintenance treatment-Clinical response compared to literature and immunological re-assessment}

Dario Roccatello ${ }^{a}$,, Savino Sciascia ${ }^{a}$, Simone Baldovino ${ }^{a}$, Daniela Rossi ${ }^{a}$, Mirella Alpa ${ }^{a}$, Carla Naretto ${ }^{a}$ Debora Di Simone ${ }^{a}$, Matteo Simoncini ${ }^{a}$, Elisa Menegattia

${ }^{a}$ Department of Rare, Immunologic, Hematologic and Immunohematologic Diseases, Center of Research of Immunopathology and Rare Diseases-Coordinating Center of Piemonte and Valle d'Aosta Network for Rare Diseases, Turin, Italy

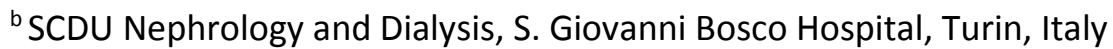

\section{Abstract}

\section{Background}

$B$ cells (BC) play a critical role in systemic lupus erythematosus (SLE). BC depletion therapy still remains an attractive option, despite the disappointing results of randomized controlled trials (RTCS).

\section{Methods}

Twelve patients with SLE [3 males, mean age 43.8 yrs (25-55)] with severe multiorgan involvement all including kidney ( 3 patients with Class IV, 4 with Class III/V and 5 with Class V, according to the International Society of Nephrology/Renal Pathology Society glomerulonephritis classification), skin lesions [10], severe polyarthralgias with arthritis [10], polyserositis [2], and lymphadenopathy [5] have been prospectively treated with an intensified B cell depletion therapy (IBCDT) protocol due to their resistance or intolerance to previous therapy (six cases) or as a front line immunosuppressive treatment in 6 women with unsatisfactory therapeutic compliance or as a specific request of a short-time immunosuppression for gestational perspectives. Protocol: Rituximab (RTX) $375 \mathrm{mg} / \mathrm{sm}$ on days 1, 8, 15, 22, and 2 more doses after 1 and 2 months, associated with $2 \mathrm{IV}$ administrations of $10 \mathrm{mg} / \mathrm{kg}$ of cyclophosphamide and 3 methylprednisolone pulses $(15 \mathrm{mg} / \mathrm{kg})$ followed by oral prednisone $(0.8 \mathrm{mg} / \mathrm{kg} / \mathrm{day}$, rapidly tapered to 5 $\mathrm{mg} /$ day by the end of the 3rd month after RTX). No further immunosuppressive maintenance therapy has been given.

\section{Results}

Patients had been followed-up for a mean of 44.5 (24-93) months. Significant decreases $(p<0.05)$ were found in the levels of ESR (baseline mean value: $55.0 \mathrm{~mm}$; 3 months: 36 ; end of follow-up: 13), anti-dsDNA antibodies (baseline: $185 \mathrm{U} ; 3$ months: 107; end of follow-up: 15), and proteinuria (baseline: $4.9 \mathrm{~g} / 24 \mathrm{~h} ; 3$ months: 0.97; end of follow-up: 0.22). C4 values (baseline $11 \mathrm{mg} / \mathrm{dl}$ ) significantly increased $(p<0.05)$ after 3 months $(22 \mathrm{mg} / \mathrm{dl})$ and at the end of the follow-up $(20 \mathrm{mg} / \mathrm{dl})$. Of the 12 patients, $9(75 \%)$ have remained well after one cycle of IBCDT, with no flare (mean 51.6 months [25-93]). Three patients relapsed after 36, 41 , and 72 months, respectively. Following re-treatment, they again showed complete remission over 1848 months of observation.

\section{Conclusions}

A promising role of RTX in an intensified protocol of induction therapy can be envisaged in patients for whom avoiding immunosuppressive maintenance therapy and sparing steroids are particularly appealing. Moreover, our data confirm in one of the longest follow-up available, the opportunity to reconsider the regimens of $B L$ depletion in the treatment of the most severe or refractory forms of SLE despite the disappointing results of RCTs. 


\section{Abbreviations}

RTX, rituximab; IS, immunosuppression; GC, glucocorticoid; F/U, follow-up; PCS, prospective color study; $\mathrm{RCS}$, retrospective cohort study; CR, complete remission; PR, partial remission; LN, lupus nephritis; NM, not mentioned; CYC, cyclophosphamide; RCT, randomized controlled trials; MTP, methylprednisolone; AZA, azathioprine; MMP, mycophenolate; Cys, cyclosporine; UTI, urinary tract infection

\section{Introduction}

B cells are thought to play an important role in the pathogenesis of systemic lupus erythematosus (SLE) [1] and [2]. B cell depletion therapy (BCDT), based on rituximab (RTX), a chimeric monoclonal antibody specific for CD20, has proved to be promising in the treatment of patients with SLE [3] and other autoimmune conditions [4], [5], [6], [7], [8], [9] and [10]. We have previously published the favorable outcome of 8 patients with severe SLE treated with an intensive short-term treatment with RTX, cyclophosphamide, and methylprednisolone pulses [11]. Our approach was able to avoid further immunosuppressive maintenance therapy [12].

BCDT is generally well tolerated, but its long-term safety profile is still debatable as most studies have follow-up data of less than 1 year.

We are now reporting on the very long-term outcome of 12 prospectively enrolled patients with renal involvement SLE (the original cohort plus an additional 7 patients) treated with the intensified BCDT (IBCDT) at our center.

Additionally, the observed results were compared to those emerging from the updated reviews of the literature on this topic focusing on study with a minimum follow-up of 24 months.

\section{Methods}

\subsection{Patients}

Twelve patients, nine women and three males, mean age 43.8 years (range $25-55$ years), with severe multiorgan involvement, including kidney ( 3 patients with Class IV, including a case of rapidly progressive glomerulonephritis, with $60 \%$ of florid crescents), 4 with Class III/V and 5 with Class V Lupus Nephritis (LN) according to the International Society of Nephrology/Renal Pathology Society Glomerulonephritis Classification), skin lesions [10 patients], severe polyarthralgias with arthritis [10], polyserositis [2], and lymphadenopathy [5], were considered eligible for RTX therapy due to their resistance or intolerance to previous therapy ( 6 cases) or as a front line treatment in 6 women with unreliable therapeutic compliance or gestational perspectives.

In non-naïve patients, prior immunosuppressive therapy included methylprednisolone pulses and oral steroids (all 6 previously treated patients), I.V. cyclophosphamide ( 2 patients), and both intravenously and orally administered cyclophosphamide for a cumulative dose of $9 \mathrm{~g}$ in one patient, azathioprine in 2 patients, mycophenolate mofetil in 2 patients, cyclosporine A in four cases, hydroxychloroquine in all 6 previously treated cases, and thalidomide in 1 patient.

RTX was administered intravenously as previously described [11] at a dose of $375 \mathrm{mg} / \mathrm{m} 2$ on days $2,8,15$, and 22. Two more doses were administered 1 and 2 months following the last weekly infusion. This treatment was combined with two pulses of $10 \mathrm{mg} / \mathrm{kg}$ cyclophosphamide (days 4 and 17) and three intravenous pulses of $15 \mathrm{mg} / \mathrm{kg}$ (days 1, 4, and 8) methylprednisolone followed by oral prednisone, 0.8 $\mathrm{mg} / \mathrm{kg} /$ day for 2 weeks rapidly tapered until $5 \mathrm{mg}$ in 3 months.

Response was evaluated by assessing the changes in clinical signs and symptoms and laboratory parameters. SLEDAI score was separately assessed by two investigators (S.S. and M.A.). 
Circulating B cells in the peripheral blood were investigated by detection of CD20+ B cells and analyzed by flow cytometry at baseline, month 1 , month 2 , and every other month thereafter.

We examined changes in T cell homeostasis following rituximab-induced B cell depletion in two patients. Analysis included flow cytometry studies at baseline (before the first RTX infusion), at months 3, 6, and 9. Whole blood samples obtained in the morning, in EDTA, were stained with monoclonal antibodies against CD45 (APC 100 eBioscience Bender Medsystems, CA, USA), CD3 (FITC eBioscience Bender Medsystems, CA, USA), CD4 (PC7 Beckman Coulter, CA, USA), CD19 (Pacific Blue ${ }^{\mathrm{TM}}$, Beckman Coulter, CA, USA), CD20 (PE Beckman Coulter, CA, USA), and CD25 (PerCP-efluor 710 eBioscience/Bender Medsystems, CA, USA), FOXP3 (PE Staining set, eBioscience Bender Medsystems, CA, USA).

\subsection{Renal response and relapse}

For the evaluation of the renal response, the Joint European League Against Rheumatism and European Renal Association-European Dialysis and Transplant Association (EULAR/ERA-EDTA) consensus statement was used [13].

In detail, a complete renal response (CR) has been defined as proteinuria $<0.5 \mathrm{~g} / 24 \mathrm{~h}$ and normal or nearnormal (within $10 \%$ of normal GFR if previously abnormal) GFR and, additionally, negative anti-DNA antibodies and normal levels of $C 3$ and C4. Partial response (PR) has been defined as $\geq 50 \%$ reduction in proteinuria to subnephrotic levels and normal or near-normal GFR.

The definition of renal flares included a reproducible increase of serum creatinine by $\geq 30 \%$ (or decrease in GFR by $\geq 10 \%$ ) and/or an increase of proteinuria $>0.5 \mathrm{~g} / 24 \mathrm{~h}$ if $\mathrm{CR}$ was initially achieved, or $\geq 50 \%$ in cases of PR.

\subsection{Statistics}

For comparison of variables at baseline and follow-up, Student's t-test was used for normally distributed parameters and the non-parametric Mann-Whitney test for non-normally distributed parameters. Correlations were calculated and significance determined by Fisher's test. Multivariable logistic regression analysis was used to identify any independent predictors of flare. Kaplan-Meier hazard plots were constructed for time to time to renal flare. For these analyses, with the Prism (GraphPad Software, CA, USA) and SPSS (IBM Corporation, NY, USA) software programs was used. $p<0.05$ was considered significant.

This study was performed according to the local rules of off-label therapy in Piedmont Region (Northwest Italy).

\section{Comparison with previously published literature}

\subsection{Selection of trials}

We searched MEDLINE and EMBASE using the terms "rituximab" and "systemic lupus erythematosus" published from January 1, 2002, to May 24, 2015. Studies were included if they were randomized controlled studies or case series with more than 10 adult patients focused on renal clinical outcomes. Studies were excluded (1) if they were reviews or expert comments or case series with fewer than 10 patients or pediatric cases, (2) if the main outcome was not clinical, and (3) if they were published only in abstract form.

When several publications under the same group of patients were found, only the most recent and comprehensive paper was considered, unless the publication was derived from another patient cohort. Among the 651 sorted publications, 15 studies met the inclusion criteria, with 14 open-label trials on LN [14], [15], [16], [17], [18], [19], [20], [21], [22], [23], [24], [25], [26] and [27] and one randomized controlled trial [28]. For each paper, selected items were systematically searched for: number of included patients, 
follow-up, indication for treatment with RTX and dosage, concomitant immunosuppressive treatment, corticosteroid dosage, and clinical and biological outcomes.

\section{Results}

\subsection{Our cohort}

The mean duration of disease and follow-up after IBCDT was 13 years (range 3-24 years) and 44.5 months (range 24-93 months), respectively.

Following IBCDT, significant decreases $(p<0.05)$ were found in the ESR levels (baseline mean value: 55.0 $\mathrm{mm}$; 3 months: $36 \mathrm{~mm}$; end of follow-up: $13 \mathrm{~mm}$ ), anti-dsDNA antibodies (baseline: $185 \mathrm{U} ; 3$ months: $107 \mathrm{U}$ ; end of follow-up: $15 \mathrm{U}$ ), and proteinuria (baseline: $4.9 \mathrm{~g} / 24 \mathrm{~h} ; 3$ months: $0.97 \mathrm{~g} / 24 \mathrm{~h}$; end of follow-up: $0.22 \mathrm{~g} / 24 \mathrm{~h}$ ). Conversely, C4 values (baseline $11 \mathrm{mg} / \mathrm{dl}$ ) significantly increased $(\mathrm{p}<0.05$ ) after 3 months (22 $\mathrm{mg} / \mathrm{dl}$ ) and at the end of follow-up ( $20 \mathrm{mg} / \mathrm{dl}$ ) ( Fig. 1 and Fig. 2). Mean serum creatinine values were 0.89 $\mathrm{mg} / \mathrm{dl}(0.6-2.6)$ at baseline, $0.87(0.6-1.7)$ after 3 months and $0.83 \mathrm{mg} / \mathrm{dl}(0.6-1.1)$ at end of follow-up. IBCDT resulted in a decrease of median global SLEDAI from 16.5 [12], [13], [14], [15], [16], [17], [18], [19], [20], [21], [22], [23], [24], [25], [26] and [27] to 4 [1], [2], [3], [4] and [5] at 12 months ( $<$ 0.001) (Fig. 3A). Constitutional symptoms, including arthralgia, weakness, and fever, disappeared in all the previously affected patients, while serositis and skin lesions gradually resolved.

All patients had complete peripheral blood-B cell depletion. The $C D 20+B$ cells were detectable in the circulation after a mean of 14.5 months (12-19 months) (Fig. 3B). Of note, at 36 months, CD20 cell number was still lower than baseline $(p<0.01)$.

Patients were not given any further immunosuppressive maintenance therapy during the follow-up, and oral prednisone was tapered to $5 \mathrm{mg} /$ day by the end of the $3 \mathrm{rd}$ month after RTX.

Nine out of 12 patients (75\%) remained in remission after one cycle of IBCDT, with no flare (mean 51.6 months [25-93]) (Fig. 4). Three patients relapsed after 36, 42, and 72 months, respectively. Following retreatment, they again showed complete remission over 18-48 months of observation.

No serious adverse events were reported ( 2 cases of infusion speed-related bradycardia). Of note, no severe infections were observed during the follow-up.

In 5 patients achieving a CR within the first 6 months, a significant longer time to repopulation of B cells in the circulation was noted $(p=0.05)$ compared with the 7 patients who achieved CR later.

As shown in Fig. 5, upon detection of B cell depletion, we observed in 9 months a 3.5-fold increase the circulating Treg (CD4+CD25+FOXP3+).

\section{Published literature}

\subsection{Open studies}

Fourteen open-label trials [14], [15], [16], [17], [18], [19], [20], [21], [22], [23], [24], [25], [26] and [27] on patients with LN met our inclusion criteria (Table 1). All used renal biological values as criteria to assess clinical outcome with the definition of complete response (CR) and partial response (PR) detailed in Table 2. A more detailed analysis has been done on 4 prospective case series with more than 24 months of followup [18], [24], [25] and [26] (in bold in the Table 1). These trials included patients mostly with active LN despite treatment (World Health Organization or International Society of Nephrology/Renal Pathology Association class III (20 patients), IV (46 patients), III-V (4 patients), and IV-V (4 patients)). Thirty-three patients had class $V$ LN. Patients received variable doses of RTX $(2 \times 1 \mathrm{~g} 4 \times 375 \mathrm{mg} / \mathrm{m2})$, and immunosuppressant agents were continued, as detailed in Table 1. 


\subsection{Randomized controlled trial}

The Lupus Nephritis Assessment with Rituximab (LUNAR) trial included patients with new or relapsed class III or IV ( \pm class V) LN, supported by a renal biopsy [28]. Patients were randomized 1:1 to receive placebo or RTX $2 \times 1$ g repeated 6 months apart in conjunction with MMF and oral prednisone. Other immunosuppressive agents were stopped. Response criteria are detailed in Table 2. Among the 144 patients enrolled (72 patients in each group), global renal response rates (CR/PR) at week 52 were not statistically different between the RTX and the placebo groups (placebo group: CR 30.6\%, PR 15.3\%; and RTX group: CR 26.4\%, PR 30.6\%).

\section{Discussion}

The results of our study show that IBCDT can be a therapeutic option for patients with LN, with a favorable very long-term safety and efficacy profile. Seventy-five percent of patients remained in remission after one cycle of IBCDT without any further immunosuppressive maintenance treatment and did not relapse. These data confirm our previous results in case of refractory SLE [11]. The main interest of these findings resides in the relatively short time of standard immunosuppression, which strongly limits the possible adverse effects of steroids and cyclophosphamide assuring a long-lasting remission without immunosuppressive maintenance therapy [12]. Besides, this scheme might also be useful in low-compliance patients and avoid prolonged hospitalization.

When comparing to the available literature, we retrieved 4 open studies with clearly reported outcomes that included at least 10 patients and had a follow-up period of at least 24 months (mean 43.75 months). The overall response rate (including complete and partial responses) ranged from $72 \%$ to $90 \%$ (median $84 \%$ ), the complete response rate from $61 \%$ to $72 \%$ (median 67\%) (Fig. 6).

In our study, we observed an overall $100 \%$ of renal response albeit with a $25 \%$ rate of relapse meanly after 50 months of symptom-free period without urinary abnormalities (Fig. 6).

\section{The following points should be considered.}

First, in the mentioned studies [18], [24], [25] and [26], RTX has been used either as two doses of 1,000 mg given 2 weeks apart (two-dose regime, commonly used in RA) or as four doses of $375 \mathrm{mg} / \mathrm{m} 2$ (four dose regime, most common regime used in lymphoma) given 1 week apart. Our scheme included two more doses administered 1 and 2 months following the last $375 \mathrm{mg} / \mathrm{m} 2$ weekly infusion (so called "4 plus 2" scheme). This represents a novelty of this open single-center study and confirms our observations in other immune-mediated diseases [29], [30], [31], [32] and [33]. Notably, a systematic review of the clinical experience of RTX for the treatment of refractory SLE suggests that the lymphoma regimen may be more effective in achieving an improvement than the two doses regimen [34]. Besides, in our cohort, a delay in repopulation was found to increase the likelihood of achieving a CR within the 6 months. This observation would support the choice of a treatment-to-target approach to achieve an adequate degree of $B$ cell depletion and a clinical response in LN. Several research groups have noted that the degree of B cell depletion is variable in SLE, but early repopulation is common in patients with a poor response to RTX [35]. The underlying reasons for the variability in B cell depletion remain elusive [7], [36], [37] and [38]. A polymorphism in Fcy receptor IIla has been shown to be important in achieving an adequate degree of $B$ cell depletion, in favor of the high-affinity genotypes Fcy receptor IIIa V158F (V, valine; F, phenylalanine) [39].

An IBCDT would therefore seem a rational approach, also taking into account that information derived from mouse models suggests that B cells exert their pathogenic role not only by producing auto-antibodies and regulating their specificities, but also by regulating the function of auto-reactive T cells, influencing antigenpresenting cells, and producing cytokines. Regulatory T cells (Treg) are critically involved in the 
pathogenesis of autoimmune diseases by suppressing effector T cells proliferation and cytokine production [40] and [41]. Interestingly, Treg frequencies have been previously shown to increase in the blood of patients with SLE following RTX [42]. In our study, in a sub-cohort of IBCDT-treated patients with LN, we noticed that, at the onset of B cell depletion, patients displayed sharp increases in CD4+CD25+FOXP3+ cells in the peripheral blood. We hypothesized that a subset of these cells might represent expanded regulatory T cells (Treg), considered to be essential in the maintenance of peripheral self-tolerance [41]. This could be a secondary consequence of clinical remission, or, if Treg are actually associated with the disease process, these data might imply that Treg are in some way B cell dependent.

Besides, as previously emphasized [43] and [44], the possible synergistic effect of RTX in combination with cyclophosphamide could not be excluded in maintaining a sustained B cells depletion.

Second, albeit in our cohort a significant decrease of proteinuria and markers of activity has been observed since month 3, the time to CR was longer in most of the cases and documented within 12 months of followup. These data suggest that the efficacy of RTX has to be evaluated over longer follow-up periods in order to increase the likelihood of capturing complete responders in the differentiation between active treatment and comparators. This observation may be in line with the fact that the Lupus Nephritis Assessment with Rituximab (LUNAR) clinical trial, investigating the efficacy of RTX in patients with LN in a double-blind, randomized trial, failed to achieve its primary endpoint assessed at week 52, although the serological improvement was statistically better in the RTX group [28]. A further consideration is worthy of note in the contest of LUNAR. One-hundred-forty-four patients from 55 centers were enrolled, resulting in a mean of 2.62 patients for each center. Such heterogeneity might have significantly influenced the results of the trial. Third, a further interest of our regimen resides in the relatively short time of standard immunosuppression associated with a noticeable steroid sparing effect. Since the end of the third month of therapy, patients were given $5 \mathrm{mg}$ prednisone. When compared to other studies with similar follow-up (bold references in Table 1), we observed a significantly lower rate of adverse events, especially in regard to severe infections (which did not occur in our cohort). The fact that RTX was not shown to be superior to conventional therapy in the LUNAR trial does not necessarily signify that it is inferior, mainly because its safety profile seems to be better than standard immunosuppression.

\subsection{Limitations of the study}

The main limitations of our study are the open non-blinded nature and the limited number of enrolled subjects. However, those are counterbalanced by the facts that our data are supported by a very long-term follow-up in a cohort of real-life SLE patients and that IBCDT allows a relatively short time of standard immunosuppression associated with a marked steroid sparing effect.

\section{Conclusions}

This prospective study brings additional long-term evidence of a role of RTX as an off-label agent in cases of LN who are intolerant or resistant to conventional therapy and need alternative therapeutic options or in patients with specific request of a short-time immunosuppression (e.g., with gestational perspectives). IBCDT obtained a long-lasting remission, which was maintained with minimal doses of prednisone by the end of the third month of therapy, avoiding the need of prolonged immunosuppression and minimizing the destructive effects of steroids. IBCDT could represent a valid alternative to offer patients treatments tailored to the individual needs based on the severity of the disease, previous medical history, or desire to have children and at same time minimizing the risk of adverse effects. 


\section{References}

[1] Yaniv G, Twig G, Shor DB, Furer A, Sherer Y, Mozes O, et al. A volcanic explosion of autoantibodies in systemic lupus erythematosus: a diversity of 180 different antibodies found in SLE patients. Autoimmun Rev 2015;14(1):75-9.

[2] Kamal A, Khamashta M. The efficacy of novel B cell biologics as the future of SLE treatment: a review. Autoimmun Rev 2014;13(11):1094-101.

[3] Gregersen JW, Jayne DR. B-Cell depletion in the treatment of lupus nephritis. Nat Rev Nephrol 2012;8(9):505-14.

[4] Greco A, De Virgilio A, Rizzo MI, Gallo A, Magliulo G, Fusconi M, et al. Microscopic polyangiitis: advances in diagnostic and therapeutic approaches. Autoimmun Rev 2015;14(9):837-44.

[5] Piatek Cl, El-Hemaidi I, Feinstein DI, Liebman HA, Akhtari M. Management of immune-mediated cytopenias in pregnancy. Autoimmun Rev 2015;14:806-11.

[6] Greco A, Rizzo MI, De Virgilio A, Gallo A, Fusconi M, Ruoppolo G, et al. Churg-Strauss syndrome. Autoimmun Rev 2015;14:341-8.

[7] Ahmed AR, Shetty S. A comprehensive analysis of treatment outcomes in patients with pemphigus vulgaris treated with rituximab. Autoimmun Rev 2015; 14:323-31.

[8] Reynaud Q, Durieu I, Dutertre M, Ledochowski S, Durupt S, Michallet AS, et al. Efficacy and safety of rituximab in auto-immune hemolytic anemia: a meta-analysis of 21 studies. Autoimmun Rev 2015;14:30413.

[9] Moulis G, Lapeyre-Mestre M, Montastruc JL, Sailler L. Exposure to non-corticosteroid treatments in adult primary immune thrombocytopenia before the chronic phase in the era of thrombopoietin receptor agonists in France. A nationwide populationbased study. Autoimmun Rev 2015;14:168-73.

[10] Erkan D, Aguiar CL, Andrade D, Cohen H, Cuadrado MJ, Danowski A, et al. 14th International Congress on Antiphospholipid Antibodies: task force report on antiphospholipid syndrome treatment trends. Autoimmun Rev 2014;13:685-96.

[11] Roccatello D, Sciascia S, Rossi D, Alpa M, Naretto C, Baldovino S, et al. Intensive shortterm treatment with rituximab, cyclophosphamide and methylprednisolone pulses induces remission in severe cases of SLE with nephritis and avoids further immunosuppressive maintenance therapy. Nephrol Dial Transplant 2011;26:3987-92.

[12] Leah E. Therapy: Rituximab for refractory SLE-patients reach lasting remission with short-term regimen. Nat Rev Rheumatol 2011;7:312.

[13] Bertsias GK, Tektonidou M, Amoura Z, Aringer M, Bajema I, Berden JH, et al. Joint European League Against Rheumatism and European Renal Association-European Dialysis and Transplant Association (EULAR/ERA-EDTA) recommendations for the management of adult and paediatric lupus nephritis. Ann Rheum Dis 2012;71: 1771-82.

[14] Sfikakis PP, Boletis JN, Lionaki S, Vigklis V, Fragiadaki KG, Iniotaki A, et al. Remission of proliferative lupus nephritis following $B$ cell depletion therapy is preceded by down-regulation of the T cell costimulatory molecule CD40 ligand: an open-label trial. Arthritis Rheum 2005;52:501-13.

[15] Vigna-Perez M, Hernandez-Castro B, Paredes-Saharopulos O, Portales-Perez D, Baranda L, AbudMendoza $C$, et al. Clinical and immunological effects of Rituximab in patients with lupus nephritis refractory to conventional therapy: a pilot study. Arthritis Res Ther 2006;8:R83.

[16] Lindholm C, Borjesson-Asp K, Zendjanchi K, Sundqvist AC, Tarkowski A, Bokarewa M. Longterm clinical and immunological effects of anti-CD20 treatment in patients with refractory systemic lupus erythematosus. J Rheumatol 2008;35:826-33.

[17] Melander C, Sallee M, Trolliet P, Candon S, Belenfant X, Daugas E, et al. Rituximab in severe lupus nephritis: early B-cell depletion affects long-term renal outcome. Clin J Am Soc Nephrol 2009;4:579-87. 
[18] Boletis JN, Marinaki S, Skalioti C, Lionaki SS, Iniotaki A, Sfikakis PP. Rituximab and mycophenolate mofetil for relapsing proliferative lupus nephritis: a long-term prospective study. Nephrol Dial Transplant 2009;24:2157-60.

[19] Li EK, Tam LS, Zhu TY, Li M, Kwok CL, Li TK, et al. Is combination rituximab with cyclophosphamide better than rituximab alone in the treatment of lupus nephritis? Rheumatology 2009;48:892-8.

[20] Pepper R, Griffith M, Kirwan C, Levy J, Taube D, Pusey C, et al. Rituximab is an effective treatment for lupus nephritis and allows a reduction in maintenance steroids. Nephrol Dial Transplant 2009;24:3717-23.

[21] Garcia-Carrasco M, Mendoza-Pinto C, Sandoval-Cruz M, Soto-Vega E, Beltran-Castillo A, JimenezHernandez M, et al. Anti-CD20 therapy in patients with refractory systemic lupus erythematosus: a longitudinal analysis of 52 Hispanic patients. Lupus 2010;19:213-9.

[22] Ramos-Casals M, Garcia-Hernandez FJ, de Ramon E, Callejas JL, Martinez-Berriotxoa A, Pallares L, et al. Off-label use of rituximab in 196 patients with severe, refractory systemic autoimmune diseases. Clin Exp Rheumatol 2010;28:468-76.

[23] Catapano F, Chaudhry AN, Jones RB, Smith KG, Jayne DW. Long-term efficacy and safety of rituximab in refractory and relapsing systemic lupus erythematosus. Nephrol Dial Transplant 2010;25:3586-92.

[24] Davies RJ, Sangle SR, Jordan NP, Aslam L, Lewis MJ, Wedgwood R, et al. Rituximab in the treatment of resistant lupus nephritis: therapy failure in rapidly progressive crescentic lupus nephritis. Lupus 2013;22:574-82.

[25] Condon MB, Ashby D, Pepper RJ, Cook HT, Levy JB, Griffith M, et al. Prospective observational singlecentre cohort study to evaluate the effectiveness of treating lupus nephritis with rituximab and mycophenolate mofetil but no oral steroids. Ann Rheum Dis 2013;72:1280-6.

[26] Jonsdottir T, Zickert A, Sundelin B, Henriksson EW, van Vollenhoven RF, Gunnarsson I. Long-term follow-up in lupus nephritis patients treated with rituximab-clinical and histopathological response. Rheumatology 2013;52:847-55.

[27] Moroni G, Raffiotta F, Trezzi B, Giglio E, Mezzina N, Del Papa N, et al. Rituximab vs mycophenolate and vs cyclophosphamide pulses for induction therapy of active lupus nephritis: a clinical observational study. Rheumatology 2014;53:1570-7.

[28] Rovin BH, Furie R, Latinis K, Looney RJ, Fervenza FC, Sanchez-Guerrero J, et al. Efficacy and safety of rituximab in patients with active proliferative lupus nephritis: the Lupus Nephritis Assessment with Rituximab study. Arthritis Rheum 2012;64: 1215-26.

[29] Roccatello D, Sciascia S, Rossi D, Alpa M, Naretto C, Russo A, et al. Long-term effects of rituximab added to cyclophosphamide in refractory patients with vasculitis. Am J Nephrol 2011;34:175-80.

[30] Roccatello D, Baldovino S, Alpa M, Rossi D, Napoli F, Naretto C, et al. Effects of antiCD20 monoclonal antibody as a rescue treatment for ANCA-associated idiopathic systemic vasculitis with or without overt renal involvement. Clin Exp Rheumatol 2008;26:S67-71.

[31] Cavallo R, Roccatello D, Menegatti E, Naretto C, Napoli F, Baldovino S. Rituximab in cryoglobulinemic peripheral neuropathy. J Neurol 2009;256:1076-82.

[32] Roccatello D, Baldovino S, Rossi D, Mansouri M, Naretto C, Gennaro M, et al. Longterm effects of antiCD20 monoclonal antibody treatment of cryoglobulinaemic glomerulonephritis. Nephrol Dial Transplant 2004;19:3054-61.

[33] Sciascia S, Naretto C, Rossi D, Bazzan M, Roccatello D. Treatment-induced downregulation of antiphospholipid antibodies: effect of rituximab alone on clinical and laboratory features of antiphospholipid syndrome. Lupus 2011;20:1106-8.

[34] Ramos-Casals M, Brito-Zeron P, Munoz S, Soto MJ, Group BS. A systematic review of the off-label use of biological therapies in systemic autoimmune diseases. Medicine 2008;87:345-64. 
[35] Vital EM, Dass S, Buch MH, Henshaw K, Pease CT, Martin MF, et al. B cell biomarkers of rituximab responses in systemic lupus erythematosus. Arthritis Rheum 2011;63: 3038-47.

[36] Dumoitier N, Terrier B, London J, Lofek S, Mouthon L. Implication of B lymphocytes in the pathogenesis of ANCA-associated vasculitides. Autoimmun Rev 2015;14: 996-1004.

[37] Visentini M, Tinelli C, Colantuono S, Monti M, Ludovisi S, Gragnani L, et al. Efficacy of low-dose rituximab for the treatment of mixed cryoglobulinemia vasculitis: Phase II clinical trial and systematic review. Autoimmun Rev 2015;14:889-96.

[38] Berman H, Rodriguez-Pinto I, Cervera R, Morel N, Costedoat-Chalumeau N, Erkan D, et al. Rituximab use in the catastrophic antiphospholipid syndrome: descriptive analysis of the CAPS registry patients receiving rituximab. Autoimmun Rev 2013; 12:1085-90.

[39] Anolik JH, Campbell D, Felgar RE, Young F, Sanz I, Rosenblatt J, et al. The relationship of FcgammaRIIla genotype to degree of $B$ cell depletion by rituximab in the treatment of systemic lupus erythematosus. Arthritis Rheum 2003;48:455-9.

[40] Sakaguchi S. Naturally arising Foxp3-expressing CD25 + CD4+ regulatory T cells in immunological tolerance to self and non-self. Nat Immunol 2005;6:345-52.

[41] von Boehmer H. Mechanisms of suppression by suppressor T cells. Nat Immunol 2005;6:338-44.

[42] Sfikakis PP, Souliotis VL, Fragiadaki KG, Moutsopoulos HM, Boletis JN, Theofilopoulos AN. Increased expression of the FoxP3 functional marker of regulatory $T$ cells following $B$ cell depletion with rituximab in patients with lupus nephritis. Clin Immunol 2007;123:66-73.

[43] Ramos-Casals M, Diaz-Lagares C, Khamashta MA. Rituximab and lupus: good in real life, bad in controlled trials. Comment on the article by Lu et al. Arthritis Rheum 2009;61:1281-2.

[44] Lu TY, Ng KP, Cambridge G, Leandro MJ, Edwards JC, Ehrenstein M, et al. A retrospective seven-year analysis of the use of $\mathrm{B}$ cell depletion therapy in systemic lupus erythematosus at University College London Hospital: the first fifty patients. Arthritis Rheum 2009;61:482-7.

Fig. 1.

Serologic profile of the SLE patients treated with In. Anti-DNA antibodies, erythrocytes sedimentation rate (ESR), and C4 were evaluated at $0,3,6$, at 12 months and then yearly.

${ }^{*} p<0.05 ;{ }^{* *} p<0.01$.

anti-dsDNA antibodies

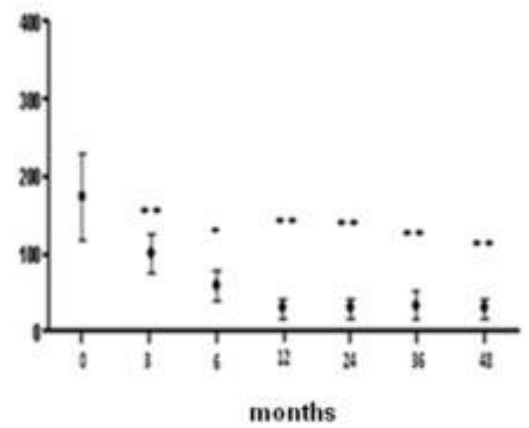

ESR

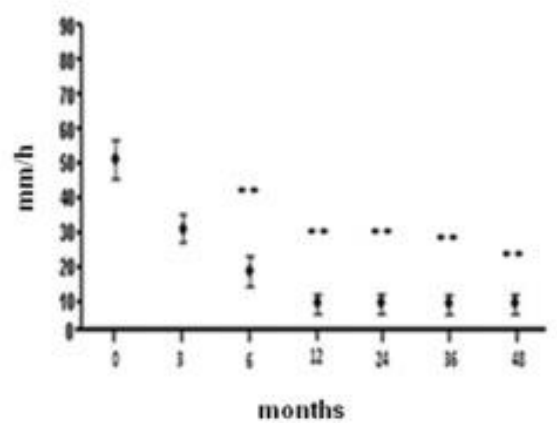

C4

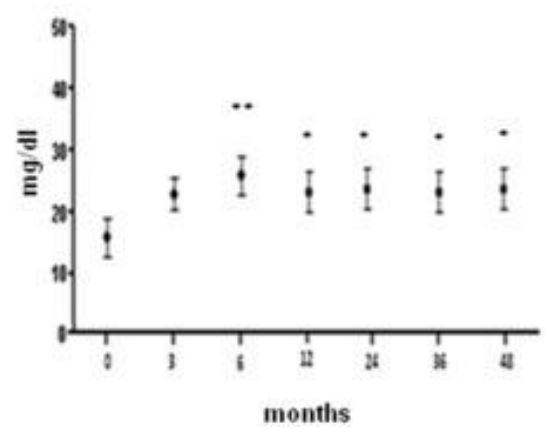


Fig. 2.

Proteinuria levels are shown. Proteinuria significantly improved since month 3 after intensified B cell depletion therapy protocol. Values are shown as mean \pm SEM. $* * * p<0.001$.

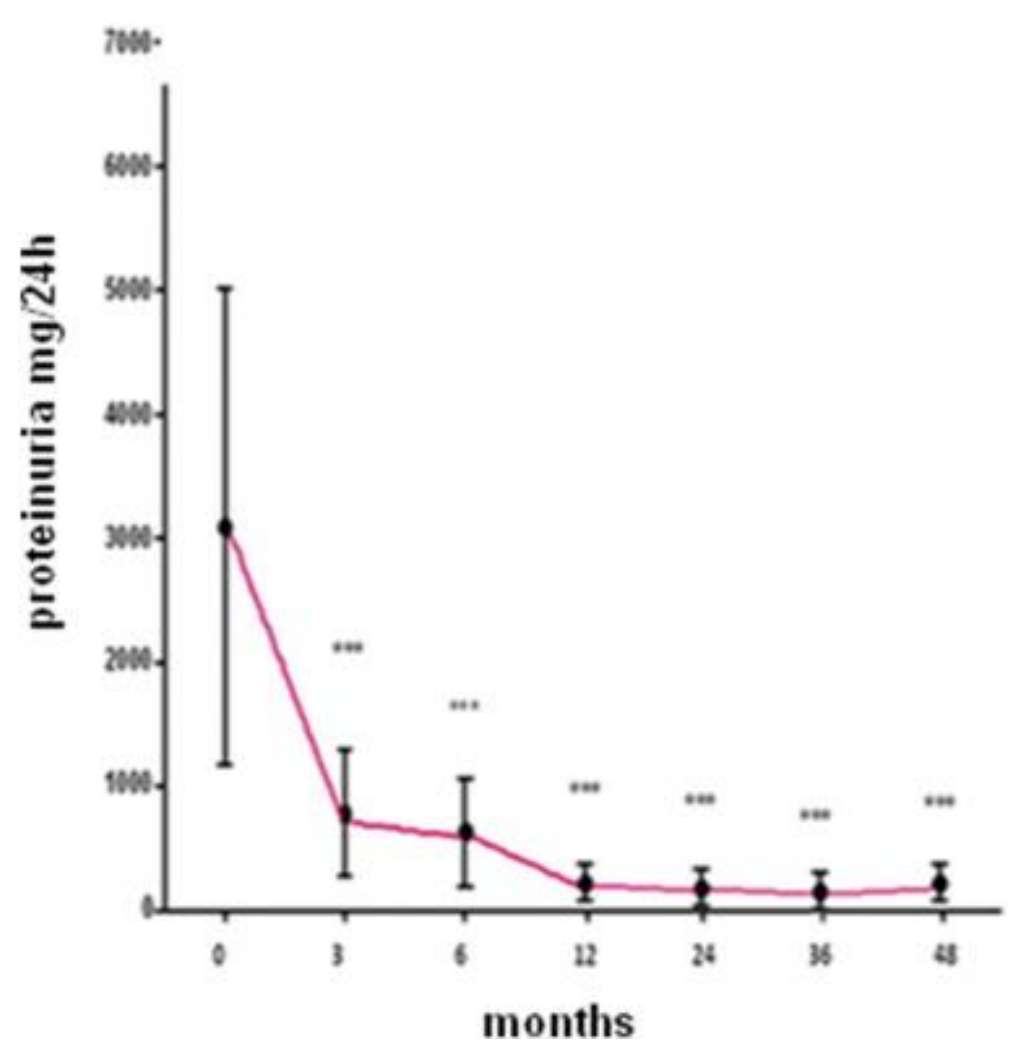

Fig. 3.

(A) SLEDAI values are shown at baseline and 12 months after intensified B cell depletion therapy protocol.

(B) Total numbers of CD20 + cells (B cells) in SLE patients before and after treatment with rituximab.

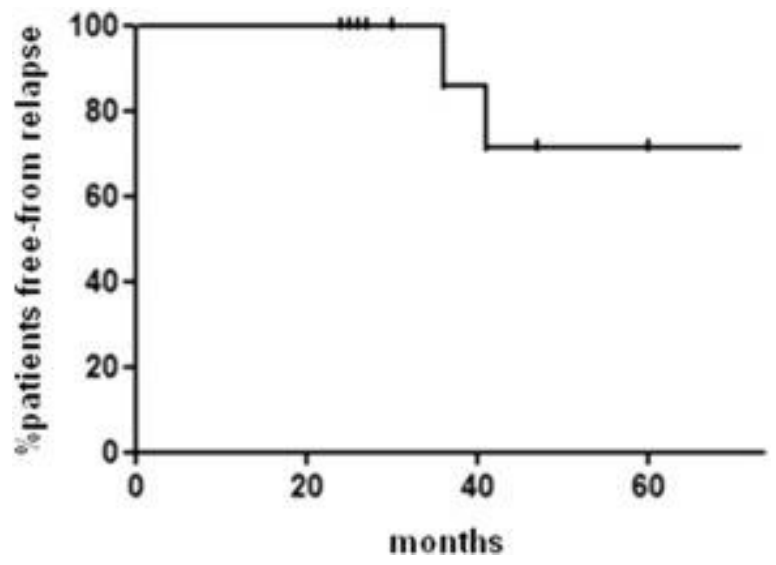


Fig. 5.

Representative dot-plots of TReg (CD4+CD25+FOXP3+, upper plots) and B cell (CD 20+, lower plots) as evaluated by flow cytometry. Samples from a responder without relapse, were analyzed before and 3, 6, and 9 months after the intensified B cell depletion therapy.

At 1 month, upon detection of B cell depletion, the patient sample showed an increase of the percentage of TReg compared with baseline.

Of note, a 3.5-fold increase of the circulating Treg (CD4+CD25+FOXP3+) has been observed over 9 months.

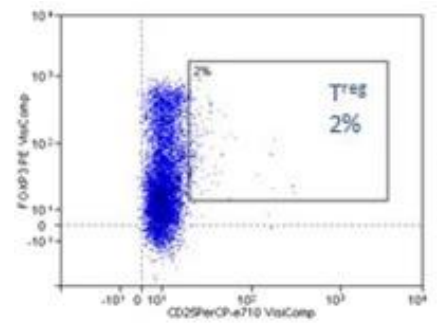

Baseline

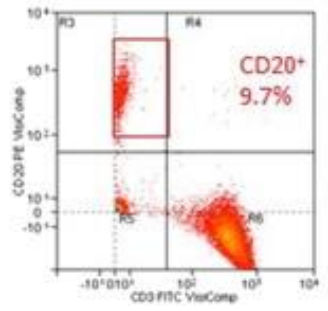

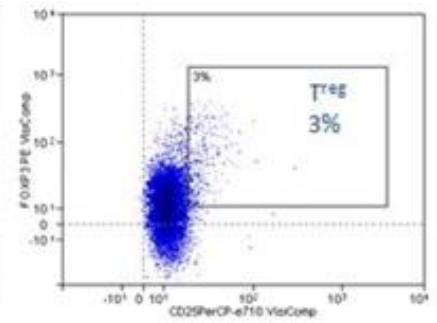

Month 1

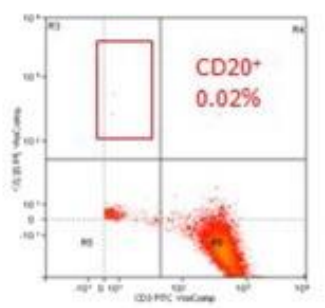

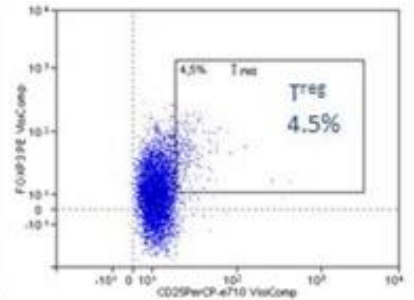

Month 6

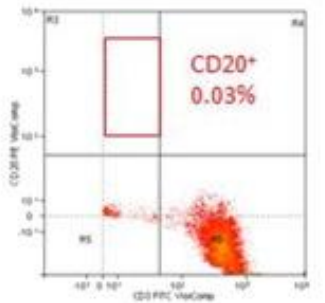

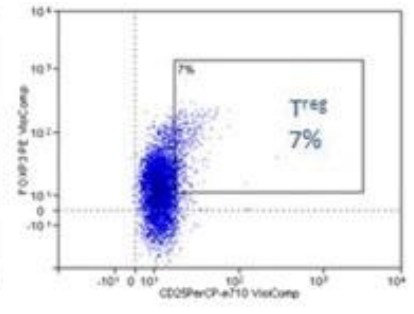

Month 9

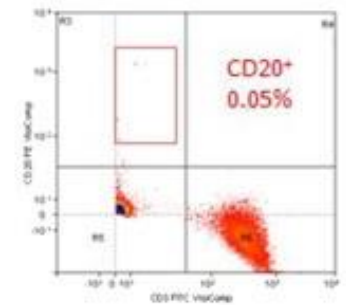

Fig. 6.

Rates of complete (CR) and partial responses (PR) and no response (NR) to RTX in patients with lupus nephritis. We retrieved 4 studies with clearly reported outcomes that included at least 10 patients and had a follow-up period of at least 24 months (mean 43.75 months). We compared these results to our data. The overall response rate (including complete and partial responses) ranged from $72 \%$ to $100 \%$ (median $88 \%$ ), the complete response rate from $61 \%$ to $100 \%$ (median $70 \%$ ). The flare rate (FR) ranged from $10 \%$ to $28 \%$ (median $24.4 \%$ ). Renal responses are characterized as decreased proteinuria, improved kidney function, and decreased expression of serological markers of disease activity, in parallel with improved clinical measures.

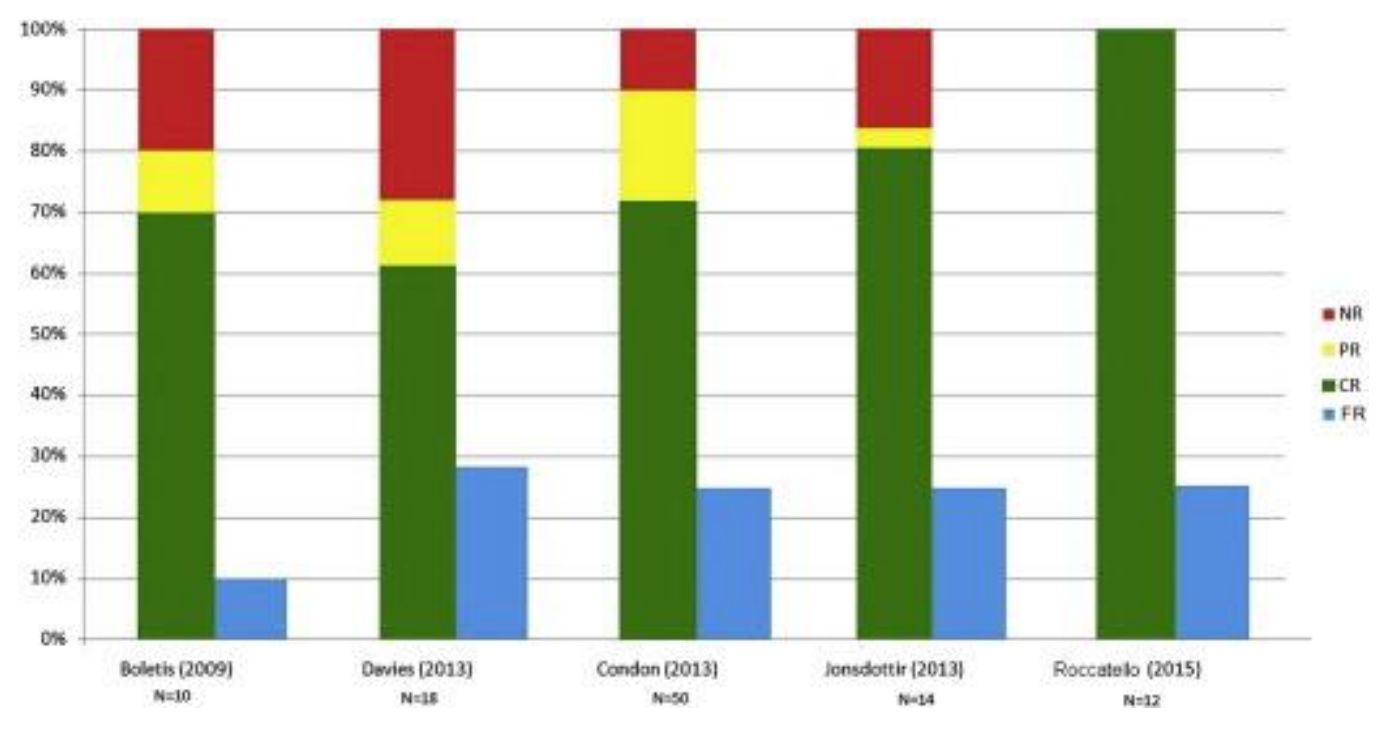


Table 1 Study characteristics and clinical outcome of rituximab-treated patients in lupus nephritis trials.

\begin{tabular}{|c|c|c|c|c|c|c|c|c|c|c|c|}
\hline Study & Year & Design & N & RTX indication & RTX dose & IS continued & IS added & CG dose (mean) & $\mathrm{F} / \mathrm{N}$ & $\begin{array}{l}\text { Clinical } \\
\text { outcome }\end{array}$ & Adverse event \\
\hline Sfikakis & 2005 & PCS & 10 & $\begin{array}{l}\text { Active LN (7 refractory. } \\
3 \text { induction) }\end{array}$ & $4 \times 375 \mathrm{mg} / \mathrm{m}^{2}$ & Oral GC & $G c$ & $\begin{array}{l}0.5 \mathrm{mg} / \mathrm{kg} / \mathrm{d} \text { day for } 4 \\
\text { weeks then tapered }\end{array}$ & $2-3$ & $\begin{array}{l}\text { CR 50\% } \\
\text { PR 30\% }\end{array}$ & NM \\
\hline Vigna-Perez & 2006 & PCS & 22 & Refractory LN & $2 \times 0.5-1 \mathrm{~g}$ & $\begin{array}{l}\text { RTX as add-on to } \\
\text { previous treatment }\end{array}$ & None & NM & 3 & $\begin{array}{l}\text { CR 23x } \\
\text { PR 32x }\end{array}$ & 1 infection \\
\hline Lindholm & 2008 & RCS & 17 & Refractory LN & $4 \times 375 \mathrm{mg} / \mathrm{m}^{2}$ & $\begin{array}{l}\text { RTX as add-on to } \\
\text { previous treatment }\end{array}$ & None & NM & 12 & $\begin{array}{l}\text { CR 128 } \\
\text { PR 538 }\end{array}$ & $\begin{array}{l}1 \text { infection, } \\
1 \text { serum sickness }\end{array}$ \\
\hline Melander & 2009 & PCS & 20 & $\begin{array}{l}\text { Active LN (18 } \\
\text { refractory. } \\
2 \text { induction) }\end{array}$ & $4 \times 375 \mathrm{mg} / \mathrm{m}^{2}$ & $\begin{array}{l}\text { RTX as add-on to } \\
\text { previous treatment }\end{array}$ & CYC in 3 pts & $0.7 \mathrm{mg} / \mathrm{kg} / \mathrm{day}$ & 22 & $\begin{array}{l}\text { CR 358 } \\
\text { PR 258 }\end{array}$ & 2 infections \\
\hline Boletis & 2009 & PCS & 10 & Refractory LN & $4 \times 375 \mathrm{mg} / \mathrm{m}^{2}$ & $\begin{array}{l}\text { RTX as add-on to } \\
\text { previous treatment }\end{array}$ & GC & $\begin{array}{l}0.5 \mathrm{mg} / \mathrm{kg} / \mathrm{day} \text { for } \\
4 \text { weeks } \\
\text { then tapered }\end{array}$ & 38 & $\begin{array}{l}\text { CR 70\% } \\
\text { PR 10\% }\end{array}$ & NM \\
\hline Li & 2009 & PCS & 19 & $\begin{array}{l}\text { Active LN } \\
\text { (6 induction) }\end{array}$ & $2 \times 1 \mathrm{~g}$ & None & $G \mathrm{C}$ and $\mathrm{CYC}$ & $\begin{array}{l}1 \times 250 \mathrm{MTP} \text { then } \\
30 \mathrm{mg} / \text { day } \\
\text { PRED for } 4 \text { days } \\
\text { then } \\
0.5 \mathrm{mg} / \mathrm{kg} / \mathrm{day} \text { for } 4 \\
\text { weeks } \\
\text { then tapered }\end{array}$ & 12 & $\begin{array}{l}\text { CR 21x } \\
\text { PR 58x }\end{array}$ & $2 / 3$ infections \\
\hline Pepper & 2009 & RCS & 18 & $\begin{array}{l}\text { Active } L N \\
\text { ( } 6 \text { induction) }\end{array}$ & $2 \times 1 g$ & $\begin{array}{l}\text { RTX as add-on to } \\
\text { previous treatment } \\
\text { but CYC }\end{array}$ & $\begin{array}{l}\text { MTP } 2 \times 500 \mathrm{mg} \text { in } 8 \mathrm{pts} \text { ) } \\
\text { and MMP } 1 \mathrm{~g}\end{array}$ & $\begin{array}{l}10 \mathrm{mg} / \text { day at } \\
\text { entrance }\end{array}$ & 12 & $\begin{array}{l}\text { CR 338 } \\
\text { PR 338 }\end{array}$ & $\begin{array}{l}1 \text { infection, } \\
2 \text { serum sickness }\end{array}$ \\
\hline Garcia-Carrasco & 2010 & RCS & 13 & Refractory LN & $2 \times 1 \mathrm{~g}$ & $\begin{array}{l}\mathrm{RTX} \text { as add-on to } \\
\text { previous treatment }\end{array}$ & $\mathrm{MTP} 2 \times 500 \mathrm{mg}$ & $\begin{array}{l}16 \mathrm{mg} / \text { day at } \\
\text { entrance }\end{array}$ & 6 & $\begin{array}{l}\text { CR 388 } \\
\text { PR 388 }\end{array}$ & $\begin{array}{l}4 \text { infections, } \\
2 \text { infusion reactions }\end{array}$ \\
\hline Ramos-Casals & 2010 & RCS & 49 & Refractory $\mathrm{LN}$ & $\begin{array}{l}4 \times 375 \mathrm{mg} / \mathrm{m}^{2} \text { or } \\
2 \times 1 \mathrm{~g}\end{array}$ & $\begin{array}{l}\text { RTX as add-on to } \\
\text { previous treatment }\end{array}$ & NM & NM & $0-26$ & CR 808 & $\begin{array}{l}11 \text { infections, } \\
7 \text { infusion reactions }\end{array}$ \\
\hline Catapano & 2010 & RCS & 11 & Refractory LN & $\begin{array}{l}4 \times 375 \mathrm{mg} / \mathrm{m}^{2} \text { or } \\
2 \times 1 \mathrm{~g}\end{array}$ & $\begin{array}{l}\text { RTX as add-on to } \\
\text { previous treatment }\end{array}$ & Heterogeneous"* & $\begin{array}{l}10 \mathrm{mg} / \mathrm{day} \text { at } \\
\text { entrance }\end{array}$ & 4 & $\begin{array}{l}\text { CR 368 } \\
\text { PR 558 }\end{array}$ & NM \\
\hline Rovin & 2012 & RCT & 144 & Active LN & $4 \times 1$ gor placebo & None & $\begin{array}{l}1.5-3 \mathrm{~g} \text { OD MMP. } \\
2 \mathrm{X} 1000 \mathrm{mg} \mathrm{MTP} \text { and } \\
\text { then tapered } \mathrm{CC}\end{array}$ & $\begin{array}{l}0.75 \mathrm{mg} / \mathrm{kg} / \mathrm{day} \\
\text { then tapered }\end{array}$ & 12 & $\begin{array}{l}\text { CR 268 } \\
\text { PR 308- } \\
- \\
\text { CR 308 } \\
\text { PR 158 }\end{array}$ & \\
\hline Davies & 2013 & PCS & 18 & Refractory LN & $2 \times 1 \mathrm{~g}$ & None & $\begin{array}{l}\text { MTP } 2 \times 500 \mathrm{mg} \\
\text { CYC } 2 \times 500 \mathrm{mg}\end{array}$ & NM & Mean 60 & $\begin{array}{l}\text { CR 61\% } \\
\text { PR 11\% }\end{array}$ & $\begin{array}{l}1 \text { infection, } \\
7 \text { infusion reactions }\end{array}$ \\
\hline Condon & 2013 & PCS & 50 & Active LN & $2 \times 1 \mathrm{~g}$ & None & $\begin{array}{l}\text { MTP } 2 \times 500 \mathrm{mg} \\
\text { MMP based on MPA level } \\
\text { (up to } 1.5 \mathrm{~g} \mathrm{BD} \text { ) }\end{array}$ & None & Mean 41 (13-60) & $\begin{array}{l}\text { CR 72\% } \\
\text { PR18\% }\end{array}$ & 5 infections \\
\hline Jonsdottir & 2013 & PCS & 14 & $\begin{array}{l}\text { Active LN } \\
\text { (2 induction) }\end{array}$ & $\begin{array}{l}4 \times 375 \mathrm{mg} / \mathrm{m}^{2} \text { or } \\
2 \times 1 \mathrm{~g}\end{array}$ & $\begin{array}{l}\text { None } \\
\text { (1 patient MMP) }\end{array}$ & $\begin{array}{l}\text { CC } 2 \times 0.5 \mathrm{~g}(2 \text { patients } \\
\text { MMP and } 2 \text { RTX monotherapy) }\end{array}$ & $\begin{array}{l}0.5 \mathrm{mg} / \mathrm{kg} / \mathrm{day} \\
\text { then tapered }\end{array}$ & $\begin{array}{l}\text { Mean } 36 \text { weeks } \\
(9-95)\end{array}$ & $\begin{array}{l}\text { CR 64X } \\
\text { PR 24\% } \\
\text { (at 1 } 1 \\
\text { year) }\end{array}$ & $\begin{array}{l}6 \text { infections, } \\
3 \text { infusion reactions }\end{array}$ \\
\hline Moroni & 2014 & PCS & 17 & $\begin{array}{l}\text { Active } L N \\
\text { (3 refractory) }\end{array}$ & $2 \times 1 \mathrm{~g}$ & None & $\begin{array}{l}\text { MTP } 3 \times 500-1000 \mathrm{mg} \text { then } G C \text {, then } \\
\text { AZA or MMP or CyS }\end{array}$ & $\begin{array}{l}0.5-0.75 \\
\text { (1)mg/kg/day for } \\
4 \text { weeks then } \\
\text { tapered. }\end{array}$ & 12 & $\begin{array}{l}\text { CR } 708 \\
\text { PR 298 }\end{array}$ & $\begin{array}{l}2 \text { infections, } \\
1 \text { infusion reaction }\end{array}$ \\
\hline Roccatello & 2015 & PCS & 12 & $\begin{array}{l}\text { Active LN } \\
\text { (6 induction in } \\
\text { naive patients) }\end{array}$ & $\begin{array}{l}4 \times 375 \mathrm{mg} / \mathrm{m}^{2} \\
\text { weekly }+2 \\
\text { further infusions } \\
\text { after } 1 \text { and } 2 \\
\text { months }\end{array}$ & None & $\begin{array}{l}\mathrm{CYC} 2 \times(10 \mathrm{mg} / \mathrm{kg}) \\
\text { and } 3 \mathrm{MIP} \times 3(15 \mathrm{mg} / \mathrm{kg})\end{array}$ & $\begin{array}{l}0.8 \mathrm{mg} / \text { die, rapidly } \\
\text { tapered to } \\
5 \mathrm{mg} / \mathrm{day} \text { by the } \\
\text { end of the } \\
3^{\text {rd }} \text { month after } \\
\text { RTX }\end{array}$ & $\begin{array}{l}\text { mean of } 44.5 \\
\text { (24-93) months }\end{array}$ & CR 100\% & $\begin{array}{l}2 \text { infusion } \\
\text { speed-related } \\
\text { bradycardia, } \\
4 \text { Un }\end{array}$ \\
\hline
\end{tabular}

Studies with more than 24 months of follow-up are marked in bold.

Table 2 Definitions of complete and partial responses in lupus nephritis trials

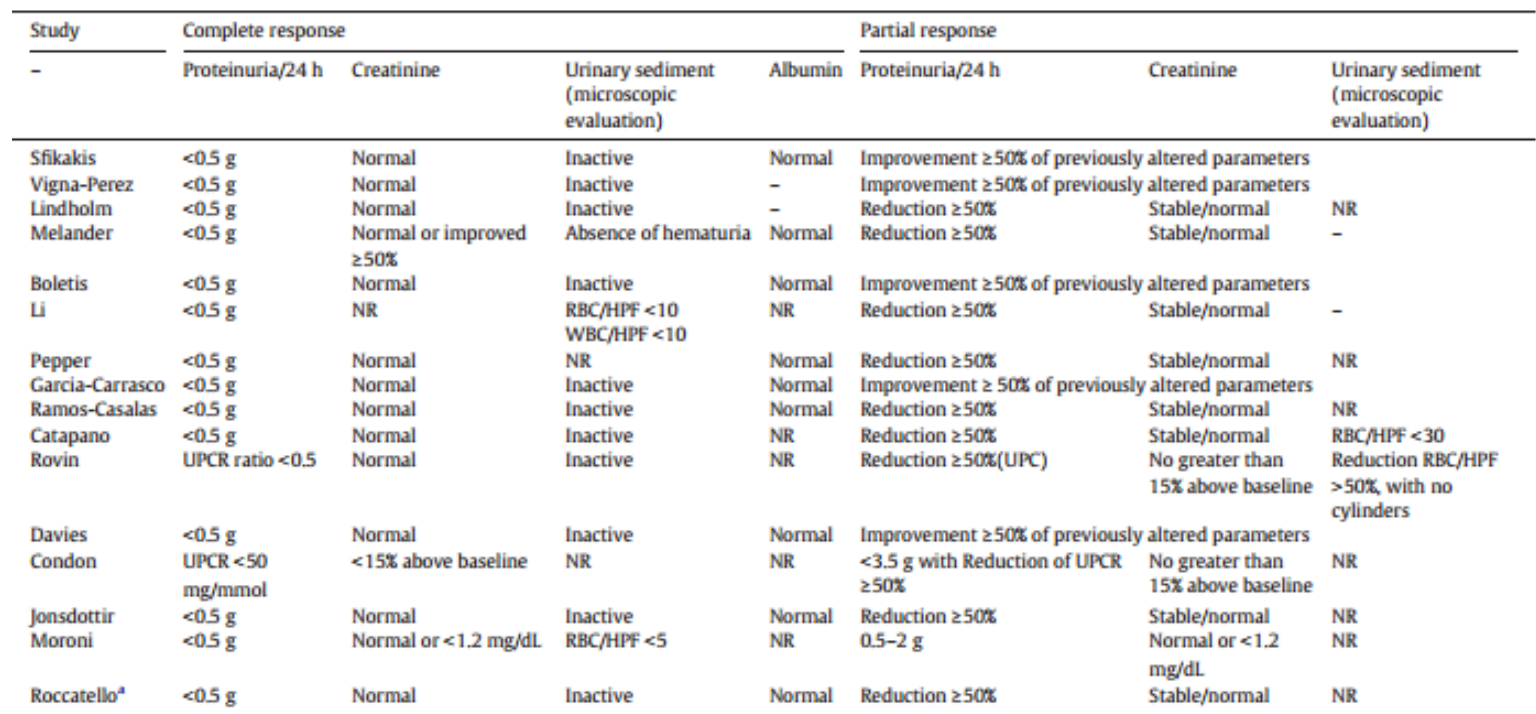

${ }^{a}$ Additionally, CR definition includes negative anti-DNA antibodies and normal levels of C3 and C4. 